\title{
Sınıf Öğretmenlerinin Mesleki Aidiyet Duyguları İle Mesleki Doyum Düzeyleri Arasındaki İlişkinin İncelenmesi: Mersin İli Örneği
}

DOI: $10.26466 /$ opus.755487

\author{
Pelin Aydınol $^{*}-$ Lütfi Üredi ${ }^{* *}$ \\ *Uzm, Hüseyin Polat Özel Eğitim Uygulama Okulu, Mersin, Türkiye \\ E-Posta: pelinaydinol@hotmail.com ORCID: 0000-0003-4915-0360 \\ ${ }^{*}$ Doç. Dr., Mersin Üniversitesi, Eğitim Fakültesi, Mersin, Türkiye \\ E-Posta: lutfiuredi@gmail.com \\ ORCID: $\underline{0000-0003-1705-1325}$
}

\begin{abstract}
$\ddot{O} z$
Bu çalışmada sını öğretmenlerinin mesleki aidiyet duyguları ile mesleki doyum düzeyleri arasındaki ilişki incelenmiştir.Bu çalışmada nicel araştırma yöntemi kullanılarak tarama modelinden yararlanılmıştır. Araştırma verileri Mesleki Aidiyet Ölçeği, Minnesota Doyum Ölçeği ve Kişisel Bilgiler Formu ile elde edilmiştir. Araştırmanın örneklemini 2018-2019 eğitim-öğretim yıl içerisinde Mersin ili Yenişehir, Toroslar, Akdeniz ve Mezitli ilçelerinde MEB'e bağhl resmi ilkokullarda görev yapan 402 sınıf öğretmeni oluşturmuştur.Veriler SPSS 25.00 programı ile analiz edilmiştir. Verilerin analizinde problem durumu için korelasyon testi, alt problemler için İlişkisiz Örneklemler için $t$-Testi, Tek Yönlü Varyans Analizi (ANOVA) uygulanmıştır. Analiz sonuçlarına göre sınıföğretmenlerinin mesleki aidiyet duyguları ile mesleki doyum düzeyleri arasında anlamlı bir fark olduğu $(p<0,01)$ bulunmuştur. Sinıf öğretmenlerinin mesleki aidiyet duyguları cinsiyet, yaş, en son mezun olunan okul değişkeleri bakımından anlaml bir farklılık göstermediği bulunmuştur. Mesleği isteyerek seçip seçmeme değişkenleri mesleki aidiyet duygularında anlamlı bir farklılık oluşturmaktadır. Sinıf öğretmenlerinin mesleki doyum düzeyleri cinsiyet, yaş, en son mezun olunan okul, mesleği isteyerek seçip seçmeme, değişkenleri baktmından anlamlı bir farklılık oluşturmamaktadır. Sını öğretmenlerinin mesleki doyum düzeyleri kıdem yılı değişkeni bakımından anlamlı farklılık göstermektedir. Yapılan araştırmalar ve elde edilen sonuçlar doğrultusunda önerilerde bulunulmuştur.
\end{abstract}

Anahtar Kelimeler: İlkokul, Sını Öğretmeni, Mesleki Aidiyet, Mesleki Doyum 


\title{
Investigation Of The Relationship Between The Primary School Teachers' Feelings Of Professional Belonging And Their Satisfaction Levels: Mersin Province Case
}

\begin{abstract}
In this study, the relationship between professional sense of belonging and professional satisfaction of classroom teachers was investigated. In this study, the survey model was used by using quantitative research method. The research data were obtained using the Occupational Belonging Scale, Minnesota Satisfaction Scale and Personal Information Form. The sample of the study consisted of 402 classroom teachers working in official primary schools affiliated to MEB in Mersin province Yeni-city, Tauruslar, Akdeniz and Mezitli districts during the 2018-2019 academic year. The data were analyzed with the SPSS 25.00 program. In the analysis of the data, correlation test for problem-lem situation, $t$-Test for Unrelated Samples for sub-problems, One-Way Var-and-Side Analysis (ANOVA) were used. According to the analysis results, it was found that there is a significant difference $(p<0.01)$ between the class teachers' sense of professional belonging and their professional satisfaction. It was found that the class teachers' professional sense of belonging did not differ significantly in terms of gender, age, and the last graduated school variables. The variables of whether to choose the profession willingly or not create a significant difference in the feelings of professional belonging. Occupational satisfaction levels of classroom teachers do not make a significant difference in terms of variables such as gender, age, the last graduated school, whether to choose the profession willingly or not. Classroom teachers' professional satisfaction levels differ significantly in terms of seniority variable. Suggestions were made in line with the researches and results obtained.
\end{abstract}

Keywords: Primary school Teacher, sense of belonging, professional satisfaction. 


\section{Giriş}

Eğitim her ne kadar bireysel olarak düşünülse de bir milletin bütününü kapsar. Öğretmenlik mesleği, bireyi aile, çevre, millet, devlet ve vatan için iyi bir insan olarak yetiştirme sanatıdır. Bu sanatla yetişen bireyler vatanını kalkındırır, devletini güçlendirir ve ailesinden başlayarak çevresini mutlu eder. $\mathrm{Bu}$ nedenle öğretmenlerin mesleklerinde gösterecekleri başarı devletin, milletin kalkınmasında rol oynar (Tekışık, 2014). Bu sebeple ülkelerin kaderini belirleyecek olan öğretmenlerdir.

Öğretmenlik mesleğinin önem ve fonksiyonu her geçen gün artıyor. Ö̆̆retim araçlarının da teknolojik açıdan gelişmesi, yeni öğretim tekniklerin çıkması, öğretmen merkezliden öğrenci merkezli eğitim anlayışına geçilmesi gibi yaşanan değişiklikler bu mesleğin önemi azaltmamıştır. Bu değişkenler öğretmenlik mesleğini daha nitelikli ve teknik hale getirmiştir (Bağçeci, Çetin ve Ünsal, 2013).

İnsan sosyal bir varlıktır. Bu yapısı gereği bir topluluğa ait olma, diğer insanlarla yakın ilişkiler kurma ihtiyacı duyar. Bu durumu Maslow'un ihtiyaçlar hiyerarşisinde de görmekteyiz. Maslow bu ihtiyaçları en alttan başlayarak bireyin fiziksel ihtiyacı, güvenlik ihtiyacı, sevme-sevilme-ait olma ihtiyac1, saygınlık-statü ihtiyacı, kendini gerçekleştirme ihtiyacı olarak beş basamakta sıralamıştır. Ait olma ihtiyacına bakıldığında aile ve bulunduğu toplumsal gruba ait olmadır (Sezer, 2009). Bu basamaktaki ihtiyaç karşılanmadan üst basamağa geçmek mümkün değildir ya da birey için üst basamak anlamsızdır. Dolayısıyla aidiyet bireyin ihtiyaçlarından biridir diye tabir edebiliriz.

Kişinin çalışmasının temel maksadı ekonomik esas olabilir. Bu durum bazı insanlar için başlıca amaç olabilmektedir. Esasında bu ana amaç etrafında bireyi çalışmaya iten birçok sebep vardır. Bireyde aidiyet duygusu oluşturmakta bunlardan biridir (Arslan, 2001). Meslek sahibi olmak ve çalışmak her ne kadar ekonomik amaçlı görünse bile iş birliği, paylaşma, sosyal statü, verimli olduğunu hissetme, zamanı düzenli yaşama olgularını bireye kazandırır. Bu olguları sağlam ve sağlıklı hale getiren de bireyin mesleki aidiyet duygusudur.

Şimşek (1999), aidiyet kavramını tanımlarken tutumu ele alarak bireyin mesleğine karşı tutumu olarak ifade etmiş̧tir. Meslekle ilgili arzu edilen ve 
edilmeyen tecrübelerin tamamı ve bunların dengelenmesinin sonucudur. Tanımların genelinden aidiyeti, bireyin mesleğine karşı tutumu olarak ifade edebiliriz.

Eğitim-öğretim ortamının temel taşı olan sınıf öğretmenlerinde mesleki aidiyet duygusu olumlu olması beklenen ve istenen bir durumdur. Mesleki doyum düzeyi yüksek olan bir sınıf öğretmeninin eğitim-öğretim ortamına ait olma duygusunun da yüksek olacağı düşünülmektedir. Mesleğinde doyum düzeyi yüksek bir öğretmenin verimliliği de artacaktır.

İş doyumu olarak tabir edilebilecek durumlar ise bireylerin yaşantıları ve duyguları ile açıklanabilir. Aynı zamanda iş görenlerin fizyolojik ve ruhsal duygularının da bir belirtisi olduğu kabul edilmektedir (Beyazsaçlı ve Bulut Serin, 2010). İş doyumunun yaklaşımları değerlendirilmek istenirse işin doyumu kişinin ihtiyaçlarını karşılama düzeyine bağlı olduğu ortaya çıkmaktadır. Kişinin işinden almak istediği ile aldığı doyum arasındaki tutarsızlık derecesine bağlı olduğu tespit edilmiştir (Mortimer, 1979). İş doyumu bireyin yapmış olduğu iş ile ilgili kendisini iyi hissetme duygusu olarak tanımlanmaktadır (Gibson, Ivancevich ve Donnelly, 2000). Doyum durumu da duygulara hitap etmektedir. İşten hoşlanma, hoşlanmama ve oluşan etki ile ilgili duyguları ifade ettiği ortaya çıkmaktadır. Doyum durumu bir kişinin yaptığı işten mutlu olmasını sağlayan bir durum olduğu düşünülmektedir (Izgar, 2003).

Bir diğer yaklaşım ise çalışanın iş yerine sağlamış olduğu katkı ile diğer çalışanların sağlamış olduğu katkıyı karşılaştırır. Bu karşılaştırma neticesinde kendisinin sağlamış olduğu katkı doğrultusunda aldıklarının daha az doyurucu olması durumunda işten doyum almamasına neden olacaktır (Mortimer, 1979). Bu durum içsel ve dışsal iş doyumu sonuçlarına da bağlıdır. İşvereninde bu sonuçları nasıl değerlendirdiği eklenir. Böylece kişiden kişiye değişen farklı seviyede iş doyum düzeyi oluşur (Gibson, Ivancevich ve Donnelly, 2000). Öğretmenin mesleki doyumu ve doyumsuzluğuna yol açan durumlar, öğretmenin kendisi hakkındaki genel görüşleri (içsel motivasyon) ve bu görüşlerin öğretmenlerin çevresindeki kişiler tarafından nasıl değerlendirildiğine bağlıdır (Tahta, 1995). İşten doyum iş görenin kurum olarak doyurulduğu ve bunun sonunca ortaya çıkan haz duygusu veya olumlu duygular olarak da belirtilmiştir (Yiğit, 2007). Öğretmenlerin, içsel ve mesleki sorunlarını asgariye indirmek okulların amaçlarını gerçekleştirmesine önemli katkılar sağlayabilir (Keskin, 20014). 
Birbiri ile böylesine ilişkili olan ve öğretmenlik mesleğine etkisi olan mesleki doyum düzeyleri ve mesleki aidiyet duyguları ile çalışmaya ihtiyaç duyulmuştur. Eğitim alanında mesleki doyum düzeyleri ve mesleki aidiyet duyguları ayrı ayrı araştııılmıştır. Alanda aralarındaki ilişkinin incelenmemesi durumu da bu ihtiyacı desteklemektedir. Bu konuda elde edilen veriler ve sonuçları alanda yapılması gerekenler hakkında ışık olacağı düşünülmektedir.

\section{Problem}

Araştırmanın problem cümlesini "Sınıf öğretmenlerinin mesleki aidiyet duyguları ile mesleki doyum düzeyleri arasında anlamlı bir ilişki var mıdır?" sorusu oluşturmaktadir.

\section{Alt Problemler}

1. Sınıf öğretmenlerinin mesleki aidiyet duyguları cinsiyete, yaşa, medeni duruma, ögrenim durumuna, mezun olunan okula, kıdem yılına, mesleği isteyerek seçip-seçmemeye ve okuldaki statüye göre anlamlı bir farklılık göstermekte midir?

2. Sınıf öğretmenlerinin mesleki doyum düzeyleri cinsiyete, yaşa, medeni duruma, ögrenim durumuna, mezun olunan okula, kıdem yılına, mesleği isteyerek seçip-seçmemeye ve okuldaki statüye göre anlamlı bir farklllık göstermekte midir?

\section{Amaç}

Ait olma duygusu bireyde ailede başlar. Çocuk anneye ait olmadan başlayarak aileye, çevreye ve okula ait olma duygusu geliştirir. Bu duygu bireyde mesleğine ait olmaya kadar devam eder. Mesleği severek yapma, mesleğinden elde ettiği doyum (maddi, manevi) ait olma duygusunu etkilemektedir. Yapılan alan taramasında Erdoğan (2006), bireyin kendini yaptığ 1 işin bir parçası gibi algılaması çalışma ortamının amacına ulaşmasında ve bireyin çalışma ortamına ait olma duygusuna sahip olmada olumlu gelişim sağlayacağından bahsetmektedir.

Bireyler, hayatlarının çoğunluğunu iş yerlerinde geçirmektedirler. Çalışma ortamlarında zamanlarının kötü geçmesi, sosyal yaşamlarına da para- 
lellik göstererek olumsuz yansıyacağı düşünülmektedir. Öğretmenler de vakitlerinin büyük bir kısmını okullarında ve öğrencileriyle birlikte geçirirler. Bu sebeple mesleklerinden elde ettikleri doyum ya da doyumsuzluk eğitimöğretim niteliğini etkilemektedir (Tekerci, 2008). Öğretmenin mesleğinden elde edeceği doyum düzeyi yükseldikçe eğitim-öğretimini yapan öğrencilerde bundan olumlu yönde etkilenecektir. Bu olgu çift yönlü olup öğrencilerin iyi bir eğitim-öğretim ortamında olması da öğretmenin mesleki doyum düzeyini olumlu etkileyecektir.

Yapılan literatür taramasında sınıf öğretmenlerine yönelik mesleki aidiyet duyguları ile ilgili çalışmalar çok azdır. Sınıf öğretmenlerinin mesleki doyum düzeylerine ilişkin çalışmalar vardır. Ancak sınıf öğretmenlerinin mesleki aidiyet duyguları ile mesleki doyum düzeylerinin incelenmesine dair bir çalışmaya rastlanmamıştır. Yapılacak bu çalışmadan elde edilecek verilerin bu doğrultuda bilgilendireceği, sorunları belirleyeceği ve çözüm odakları için ışık tutacağı düşünülmektedir.

\section{Yöntem}

Araştırmanın bu bölümünde araştırma modeli, araştırmanın evren ve örneklemi, veri toplama araçları veri analizi hakkında açılamalara yer verilmiştir.

\section{Araştırma Modeli}

Bu araştırma farklı değişkenler açısından sınıf öğretmenlerinin mesleki aidiyet duyguları ile mesleki doyum düzeylerini ve aralarındaki ilişkiyi belirlemeyi amaçladığından ilişkisel tarama modeli olan nicel bir araştırmadır.

Nicel araştırmada veri toplama teknikleri ölçek, test ve anket kullanıldığ görülmektedir (Gülbahar ve Alper, 2009). Nicel araştırmalarda geçerlik ve güvenirlik analizi yapılır, bağımlı değişkenler ve bağımsız değişkenlerin ilişkisinin belirlenmesindeki etkiyi ortaya koyar (Tomakin, 2007).

İlişkisel tarama modeli, iki ve daha çok sayıdaki değişen arasında birlikte değişim varlığını ve/veya derecesini belirlemeyi amaçlayan araştırma modelidir. Bu tür bir düzenlemede, aralarında ilişki aranacak değişkenler, tekil taramada olduğu gibi, ayrı ayrı sembolleştirilir. Ancak bu sembolleştirme (değer verme, ölçme), ilişkisel bir çözümlemeye olanak verecek şekilde yapılmak zorundadır (Karasar, 1994). 


\section{Evren ve Örneklem}

Araştırmanın evrenini Mersin'de 2018-2019 öğretim yılında görev yapan sınıf öğretmenleri oluşturmaktadır. Araştırmanın Örneklemini 2018-2019 eğitimöğretim yılı içerisinde Mersin ili Yenişehir, Toroslar, Akdeniz ve Mezitli ilçelerinde MEB'e bağlı kamu ilkokullarında görev yapan ve araştırmaya dahil olmaya gönüllü olan 402 sinıf öğretmeni oluşturmuştur. Christensen, Johnson ve Turner (2015)'ın belirlediği örneklem oranlarına göre yeterli sayı olduğu düşünülmektedir. Araştırmaya katılan 402 sınıf öğretmeninden Yenişehir ilçesinden 164 sınıf öğretmeni, Mezitli ilçesinden 66 sınıf öğretmeni, Akdeniz ilçesinde 87 sunıf öğretmeni, Toroslar ilçesinde 85 sınıf öğretmeni gönüllü olarak araştırmaya dahil olmuştur.

\section{Bulgular}

Sınıf öğretmenlerinin mesleki doyum düzeylerinde ve mesleki aidiyet duygularında cinsiyet değişkeni açısından anlamlı bir farklılık olup olmadığını incelemek için t-Testi ve Ki Kare testi; medeni durum, mezun olunan okul, mesleği isteyerek seçip seçmeme değişkeni açısından anlamlı bir farklılık olup olmadığını incelemek için t-Testi; yaş, öğrenim durumu, kıdem yıll, okuldaki statü ve okulun bulunduğu ilçe değişkenleri açısından anlamlı bir farklılık olup olmadığını incelemek için üç veya daha fazla kategoriden oluşması sebebiyle Tek Yönlü Varyans Analizi (ANOVA) uygulanmıştır. Mesleki doyum düzeyleri ile mesleki aidiyet duyguları arasında anlamlı fark olup olmadığını incelemek için Pearson Korelasyon analizi yapılmıştır.

\section{Demografik Bulgular}

Tablo 1: Araştırma Örneklemine İlişkin Katılımcılarnn Yüzde ve Frekans Tablosu

\begin{tabular}{lll}
\hline Değişken & $\mathbf{N}$ & $\mathbf{\%}$ \\
\hline Cinsiyet & & \\
Bayan & 236 & 58,7 \\
Erkek & 166 & 41,3 \\
\hline Yaş & & \\
$20-25$ yaş & 27 & 6,7 \\
$26-30$ yaş & 63 & 15,7 \\
$31-35$ yaş & 76 & 18,9 \\
$36-40$ yaş & 66 & 16,4 \\
$41-45$ yaş & 45 & 11,2 \\
46 yaş ve üzeri & 125 & 31,1 \\
\hline
\end{tabular}




\begin{tabular}{|c|c|c|}
\hline \multicolumn{3}{|l|}{ Medeni Durum } \\
\hline Evli & 312 & 77,6 \\
\hline Bekar & 90 & 22,4 \\
\hline \multicolumn{3}{|l|}{ Öğrenim Durumu } \\
\hline Ön lisans & 60 & 14,9 \\
\hline Lisans & 311 & 77,4 \\
\hline Yüksek lisans & 20 & 5 \\
\hline Doktora & 10 & 2,5 \\
\hline Diğer & 1 & 0,2 \\
\hline \multicolumn{3}{|l|}{ En Son mezun olduğunuz okul } \\
\hline Eğitim Fakültesi & 309 & 76,9 \\
\hline Diğer & 93 & 23,1 \\
\hline \multicolumn{3}{|l|}{ Kıdem yılı } \\
\hline $1-5$ yil & 57 & 14,2 \\
\hline $6-10 \mathrm{yll}$ & 100 & 24,9 \\
\hline $11-15$ yll & 57 & 14,2 \\
\hline $16-20 \mathrm{yll}$ & 46 & 11,4 \\
\hline $21-25 \mathrm{yll}$ & 30 & 7,5 \\
\hline 25 yıl ve üzeri & 112 & 27,9 \\
\hline \multicolumn{3}{|l|}{ Mesleği İsteyerek Seçip Seçmemeniz } \\
\hline İsteyerek Seçtim & 342 & 85,1 \\
\hline İstemeyerek Seçtim & 60 & 14,9 \\
\hline \multicolumn{3}{|l|}{ Okuldaki Statünüz } \\
\hline Kadrolu öğretmen & 387 & 96,3 \\
\hline Sözleşmeli öğretmen & 4 & 1 \\
\hline $\begin{array}{l}\text { Ek ders karşllı̆̆ görev yapan ücretli öğretmen } \\
\text { Diğer }\end{array}$ & 11 & 2,7 \\
\hline \multicolumn{3}{|l|}{ Okulunuzun Bulunduğu İlçe } \\
\hline Yenişehir & 164 & 40,8 \\
\hline Mezitli & 66 & 16,4 \\
\hline Akdeniz & 87 & 21,6 \\
\hline Toroslar & 85 & 21,1 \\
\hline Toplam & 402 & 100,0 \\
\hline
\end{tabular}

\section{Probleme Ait Bulgular}

Sını öğretmenlerinin mesleki aidiyet duyguları ile mesleki doyum düzeyleri arasında anlamlı bir ilişki var mıdır?

Tablo 2. Sını öğretmenlerinin Mesleki Doyum Düzeylerine İlişkin Aritmetik Ortalama ve Standart Sapma Sonuçlarn

\begin{tabular}{llllll}
\hline Değişken & N & En Düşük & En Yüksek & $X^{-}$ & Ss \\
\hline Sinıf öğretmenleri & 402 & 30 & 100 & 72,81 & 13,05 \\
\hline
\end{tabular}


Tablo 2 incelendiğinde alınan verilere göre sınıf öğretmenlerinin mesleki doyum düzeyi puanlarının en düşük 30, en yüksek 100 olduğu, tüm sorulara verilen ifadelerin aritmetik ortalamasının $(X=72,81)$ şeklinde olduğu görülmektedir.

Tablo 3. Stnıf öğretmenlerinin Mesleki Aidiyet Düzeylerine İlişkin Aritmetik Ortalama ve Standart Sapma Sonuçlar

\begin{tabular}{llllll}
\hline Değişken & $\mathbf{N}$ & En Düşük & En Yüksek & $\mathbf{X}$ & Ss \\
\hline Sinıf öğretmenleri & 402 & 37 & 160 & 98,62 & 18,90 \\
\hline
\end{tabular}

Mesleki Aidiyet ölçeğinde öğretmenlerin mesleki aidiyet duyguları en düşük (32 puan), en yüksek (160 puan) olarak değerlendirilmiştir. Tablo 3 incelendiğinde alınan verilere göre sınıf öğretmenlerinin mesleki aidiyet duyguları puanlarının en düşük 37, en yüksek 160, tüm sorulara verilen aritmetik ortalamasının $\left(X^{-}=98,62\right)$ şeklindedir.

Tablo 4. Sını öğretmenlerinin Mesleki Aidiyet Duyguları ile Mesleki Doyum Düzeylerine İlişkin Pearson Korelasyon Değerleri Sonuçlan

\begin{tabular}{|c|c|c|c|c|}
\hline Değişken & $\mathbf{N}$ & $x$ & $\mathbf{R}$ & $\mathbf{P}$ \\
\hline Mesleki Aidiyet & 402 & 98,62 & & \\
\hline Mesleki Doyum & 402 & 72,81 & ,337 & , 000 \\
\hline
\end{tabular}

Sınıf öğretmenlerinin mesleki aidiyet duyguları ile mesleki doyum düzeyleri arasında anlamlı bir ilişki olup olmadığına bakıldığında Tablo 4'teki verilere göre sınıf öğretmenlerinin mesleki doyum düzeyleri ile mesleki aidiyet duyguları arasında pozitif yönde anlamlı bir ilişki bulunmaktadır. Bu demek oluyor ki mesleki doyum düzeyleri ile mesleki aidiyet duyguları birbirleriyle ilişkili olarak artmaktadır $(p<0,01)$. Yani sınıf öğretmenlerinin mesleki aidiyet duyguları arttıkça mesleki doyum düzeyleri de artmaktadır. Yine sınıf öğretmenlerinin mesleki doyum düzeyleri arttıkça mesleki aidiyet duyguları da artmaktadır denilebilir.

\section{Alt Problemlere Ait Bulgular}

Birinci alt probleme "Sınıf öğretmenlerinin cinsiyet, yaş, mezun olunan okul, mesleği isteyerek seçip-seçmeme değişkenlerine göre mesleki aidiyet duyguları, anlamlı bir farklılık göstermekte midir?" ait bulgular: 
Mesleki Aidiyet Ölçeğinden Alınan Puanların Cinsiyet Değişkenine Göre Analiz Bulgular

Sınıf öğretmenlerinin mesleki aidiyet duygularında cinsiyet değişkeni açısından anlamlı bir fark olup almadığını incelemek için t-Testi uygulanmıştır.

Tablo 5. Mesleki Aidiyet Ölçeği Puanlannın Cinsiyet Değişkenine Göre t-Testi Sonuçları

\begin{tabular}{lllllll}
\hline Değişken & $\mathbf{N}$ & $\mathbf{X}$ & ss & Sd & $\mathbf{t}$ & $\mathbf{p}$ \\
\hline Bayan & 236 & 98,44 & 18,33 & \multirow{2}{*}{400} & \multirow{2}{*}{223} & \multirow{2}{*}{823} \\
\hline Erkek & 166 & 98,87 & 19,74 & & \\
\hline
\end{tabular}

Kadın ve erkek sınıf öğretmenlerinin mesleki aidiyet duygularında Tablo 5 'te yer alan veriler incelendiğinde t-Testi sonuçlarına göre anlamlı bir farkl1lık bulunmamaktadır $(p>0,05)$. Öğretmenlerin mesleki aidiyet duygularında cinsiyet olumlu ya da olumsuz etki yaratmamaktadır. Cinsiyet değişkeni mesleki aidiyet duygularında belirleyici değildir.

Mesleki Aidiyet Ölçeğinden Alınan Puanlarnn Yaş Değisskenine Göre Analiz Bulgular

Sınıf öğretmenlerinin mesleki aidiyet duygularında yaş değişkeni açısından anlamlı bir fark olup almadığını incelemek için Tek Yönlü Varyans Analizi (ANOVA) testi uygulanmıştır.

Tablo 6: Mesleki Aidiyet Ölçeği Puanlannın Yaş Değişkenine Göre Aritmetik Ortalama ve Standart Sapma Değerleri

\begin{tabular}{llll}
\hline Değişken & $\boldsymbol{N}$ & $\boldsymbol{X}^{-}$ & $S \boldsymbol{S}$ \\
\hline $\mathbf{2 0 - 2 5}$ yaş & 27 & 106,25 & 16,67 \\
\hline $\mathbf{2 6 - 3 0}$ yaş & 63 & 107,22 & 18,55 \\
\hline $\mathbf{3 1 - 3 5}$ yaş & 76 & 106,46 & 17,03 \\
\hline $\mathbf{3 6 - 4 0}$ yaş & 66 & 112,60 & 20,10 \\
\hline $\mathbf{4 1 - 4 5}$ yaş & 45 & 110,44 & 16,74 \\
\hline 46 yaş ve üzeri & 125 & 113,49 & 19,25 \\
\hline Toplam & 402 & 110,20 & 18,60 \\
\hline
\end{tabular}

Sinıf öğretmenlerinin yaş değişkenine göre mesleki aidiyet ölçeğinden aldıkları toplam ortalama puana bakıldığında $(X=110,20)$ olduğu görülmektedir. 
Tablo 7. Mesleki Aidiyet Ölçeği Puanlarnnı Yaş Değişsenine Göre Tek Yönlü Varyans Analizi (ANOVA) Sonuçları

\begin{tabular}{|c|c|c|c|c|c|c|c|}
\hline $\begin{array}{l}\text { Varyansın } \\
\text { Kaynağı }\end{array}$ & $\begin{array}{l}\text { Kareler } \\
\text { toplamı }\end{array}$ & $\begin{array}{l}\text { Kareler } \\
\text { Ortalaması }\end{array}$ & Sd & F & $\mathbf{P}$ & $\begin{array}{l}\text { Anlamlı } \\
\text { Gruplanı }\end{array}$ & Fark \\
\hline $\begin{array}{l}\text { Gruplar } \\
\text { arasi }\end{array}$ & 3783,375 & 756,675 & 5 & \multirow{3}{*}{2,220} & \multirow{3}{*}{,052 } & & \multirow{3}{*}{ - } \\
\hline Grup içi & 134957,072 & 340,801 & 396 & & & & \\
\hline Toplam & 138740,448 & & 401 & & & & \\
\hline
\end{tabular}

Sınıf öğretmenlerinin mesleki aidiyet duygularında yaş değişkeni Tek Yönlü Varyans Analizi (ANOVA) Tablo 7'ye göre anlamlı bir farklılık bulunmamaktadır $(p>0,05)$. Tablo 6'ya göre en yüksek mesleki aidiyet duygusu $36-40$ yaş $\left(X^{-}=112,60\right)$ arası öğretmenlerde olduğu görülmektedir. Tabloya göre en düşük mesleki aidiyet duygusu 20-25 yaş $\left(X^{-}=106,25\right)$ arası öğretmenlerde olduğu görülmektedir.

\section{Mesleki Aidiyet Ölçeğinden Alınan Puanlarn En Son Mezun Olunan Okul Değişkenine Göre Analiz Bulgular}

Araştırmaya katılan sınıf öğretmenlerinin mesleki aidiyet duygularının en son mezun olunan okul değişkenine göre farklılık olup olmadığını incelemek için t-Testi uygulanmıştır.

Tablo 8. Mesleki Aidiyet Ölçeği Puanlarnnn En Son Mezun Olunan Okul Değişkenine Göre t-Testi Sonuçlan

\begin{tabular}{lllllll}
\hline Değişken & $\mathbf{N}$ & $\boldsymbol{X}^{-}$ & ss & Sd & $\mathbf{t}$ & $\mathbf{p}$ \\
\hline Eğitim Fakültesi & 309 & 109,39 & 18,13 & \multirow{2}{*}{400} & \multirow{2}{*}{$-1,60$} & \multirow{2}{*}{110} \\
\hline Diğgr & 93 & 106,35 & 18,39 & & & \\
\hline
\end{tabular}

Sınıf öğretmenlerinin sahip oldukları mesleki aidiyet duyguları en son mezun olunan okul değişkenine göre anlamlı bir farklılık göstermemektedir $(p>0.05)$. Araştırmaya katılan öğretmenlerin ortalamalarına bakıldığında eğitim fakültesi mezunu öğretmenlerin $\left(X^{-}=109,39\right)$ ile diğer fakültelerden mezun öğretmenlere $\left(X^{-}=106,35\right)$ göre mesleki aidiyet duygularının daha fazla olduğu görülmektedir. En son mezun olunan okul değişkeninde öğretmenlerin mesleki aidiyet duyguları ortalamaları farklı çıkmasına rağmen bu farklılık istatistiksel olarak anlamlı fark oluşturmamaktadır. 
Mesleki Aidiyet Ölçeğinden Alınan Puanların Mesleği İsteyerek Seçip Seçmeme Değişkenine Göre Analiz Bulgularn

Sınıf öğretmenlerinin mesleki aidiyet duygularının mesleği isteyerek seçip seçmeme değişkenine göre farklı olup olmadığına bakmak için t-Testi uygulanmıştır.

Tablo 9. Mesleki Aidiyet Ölçeği Puanlarnnın Mesleği İsteyerek Seçip Seçmeme Değişkenine Göre t-Testi Sonuçları

\begin{tabular}{lllllll}
\hline Değişken & $\mathbf{N}$ & $\boldsymbol{X}^{-}$ & ss & Sd & $\mathbf{t}$ & $\mathbf{p}$ \\
\cline { 1 - 4 } İsteyerek seçtim & 342 & 111,71 & 18,63 & \multirow{2}{*}{400} & \multirow{2}{*}{3,957} & \multirow{2}{*}{000} \\
\cline { 1 - 5 } İstemeyerek seçtim & 60 & 101,60 & 16,01 & & & \\
\hline
\end{tabular}

Araştırmaya katılan sınıf öğretmenlerinin mesleki aidiyet duyguları mesleği isteyerek seçip seçmeme değişkenine göre anlamlı bir farklılık göstermektedir $(p<0,05)$. Başka bir ifadeyle sinıf öğretmenlerinin mesleki aidiyet duyguları mesleği isteyerek seçip seçmemelerine bağlı olarak farklılaşmaktadır. Mesleği isteyerek seçen sinıf öğretmenlerinin $(X=111,71)$ mesleki aidiyet duyguları mesleği istemeyerek seçen sınıf öğretmenlerinin $(X=101,60)$ mesleki aidiyet düzeylerine göre daha olumludur.

İkinci alt probleme "Sınıf öğretmenlerinin mesleki doyum düzeyleri cinsiyet, yaş, mezun olunan okul, kıdem yıll, mesleği isteyerek seçip-seçmeme değişkenlerine göre anlamlı bir farklılık göstermekte midir?" ait bulgular:

\section{Mesleki Doyum Ölçeğinden (Minnesota Doyum Ölçeği) Alınan Puanlarnn} Cinsiyet Değişkenine Göre Analiz Bulgularn

Sınıf öğretmenlerinin mesleki doyum düzeylerinde cinsiyet değişkeni açısından anlamlı bir fark olup almadığını incelemek için t-Testi uygulanmıştır.

Tablo 10. Mesleki Doyum Ölçeği (Minnesota Doyum Ölç̧ĕ̆i) Puanlarının Cinsiyet Değişkenine Göre t-Testi Sonuçlan

\begin{tabular}{lllllll}
\hline Değişken & $\mathbf{N}$ & $\boldsymbol{X}$ & ss & Sd & $\mathbf{t}$ & $\mathbf{p}$ \\
\hline Bayan & 236 & 73,07 & 13,26 & \multirow{2}{*}{400} & \multirow{2}{*}{, 478} & \multirow{2}{*}{633} \\
\hline Erkek & 166 & 72,43 & 12,76 & & & \\
\hline
\end{tabular}

Tablo 10'daki veriler incelendiğinde sınıf öğretmenlerinin mesleki doyum düzeylerinin cinsiyet değişkenine göre anlamlı farklılık göstermediği bulunmuştur $(p>0,05)$. Cinsiyet değişkeni mesleki doyum düzeyinde anlamlı bir 
farklılık göstermemiştir. Mesleki doyum düzeylerinde kadın ve erkek öğretmenlerin ortalama puanlarına bakıldığında kadın öğretmenlerin ortalama puanları $(X=73,07)$, erkek öğretmenlerin ortalama puanlarından $(X=72,43)$ daha fazladır.

\section{Mesleki Doyum Ölçeğinden (Minnesota Doyum Ölçeği) Alınan Puanlarnn Yaş Değişkenine Göre Analiz Bulgulan}

Araştırmaya katılan öğretmenlerin yaş değişkenine ilişkin mesleki doyum düzeylerinin farklılaşıp farklılaşmadığını belirlemek üzere Tek Yönlü Varyans Analizi (ANOVA) yapılmıştır.

Tablo 11. Mesleki Doyum Ölçeği (Minnesota Doyum Ölçeği) Puanlarının Yaş Değişkenine Göre Aritmetik Ortalama ve Standart Sapma Değerleri

\begin{tabular}{llll}
\hline Değişken & $N$ & $X^{-}$ & Ss \\
\hline $\mathbf{2 0 - 2 5}$ yaş & 27 & 72,55 & 11,58 \\
\hline $\mathbf{2 6 - 3 0}$ yaş & 63 & 74,36 & 13,04 \\
\hline $\mathbf{3 1 - 3 5}$ yaş & 76 & 69,43 & 16,01 \\
\hline $\mathbf{3 6 - 4 0}$ yaş & 66 & 71,00 & 11,90 \\
\hline $\mathbf{4 1 - 4 5}$ yaş & 45 & 73,62 & 12,95 \\
\hline $\mathbf{4 6}$ yaş ve üzeri & 125 & 74,80 & 11,59 \\
\hline Toplam & 402 & 72,81 & 13,05 \\
\hline
\end{tabular}

Yaş değişkenine göre sınıf öğretmenlerinin mesleki doyum düzeyi ortalama puanlarına bakıldığında en yüksek 46 yaş ve üzeri $(X=74,80)$, en düşük 31-35 yaş arası $(X=69,43)$ olduğu görülmektedir. Genel ortalama $(X=$ $72,81)^{\prime}$ dir.

Tablo 12. Mesleki Doyum Ölçeği (Minnesota Doyum Ölçeği) Puanlarnnın Yaş Değişkenine Göre Tek Yönlï Varyans Analizi (ANOVA) Sonuçlan

\begin{tabular}{|c|c|c|c|c|c|c|}
\hline $\begin{array}{l}\text { Varyansın } \\
\text { Kaynağı }\end{array}$ & $\begin{array}{l}\text { Kareler } \\
\text { toplamı }\end{array}$ & $\begin{array}{l}\text { Kareler } \\
\text { Ortalaması }\end{array}$ & $S d$ & F & $\mathbf{P}$ & Anlamlı Fark Gruplar \\
\hline Gruplar arası & 1761,113 & 352,223 & 5 & \multirow{3}{*}{2,096} & \multirow{3}{*}{, 065} & \multirow{3}{*}{ Yok } \\
\hline Grup içi & 66530,519 & 168,006 & 396 & & & \\
\hline Toplam & 68291,632 & & 401 & & & \\
\hline
\end{tabular}

Tablo 12 incelendiğinde sınıf öğretmenlerinin mesleki doyum düzeyleri yaş değişkeni açısından anlamlı farklılık göstermemektedir ( $p>0,05)$. Başka bir ifadeyle yaş değişkeni sınıf öğretmenlerinin mesleki doyum düzeylerinde anlamlı bir farklılaşmaya sebep olmamıştır. 
Mesleki Doyum Ölçeğinden (Minnesota Doyum Ölçeği) Alınan Puanlarn En Son Mezun Olunan Okul Değişkenine Göre Analiz Bulgularn

Sınıf öğretmenlerinin mesleki doyum düzeylerinin en son mezun olunan okul değişkenine göre farklı olup olmadığını incelemek için t-testi uygulanmiştır.

Tablo 13. Mesleki Doyum Ölçeği (Minnesota Doyum Ölçeği) Puanlarnnın En Son Mezun Olunan Okul Değişkenine Göre t-testi Sonuçlarn

\begin{tabular}{lllllll}
\hline Değişken & $\mathbf{N}$ & $\boldsymbol{X}^{-}$ & ss & Sd & $\mathbf{t}$ & $\mathbf{p}$ \\
\hline Eğitim Fakültesi & 309 & 72,16 & 13,38 & \multirow{2}{*}{400} & \multirow{2}{*}{$-1,814$} & \multirow{2}{*}{0,70} \\
\cline { 1 - 7 } Diğer Fakülteler & 93 & 74,95 & 11,66 & & & \\
\hline
\end{tabular}

Sını öğretmenlerinin mesleki doyum düzeyleri en son mezun olunan okul değişkenine göre anlamlı bir farklılık göstermemektedir $(p>0,05)$. Eğitim fakültesi sınıf öğretmenlerinin sayısı $(N=309)$ diğer fakültelerden mezun olan sınıf öğretmenlerinin sayısından ( $N=93$ ) fazladır. Minnesota doyum ölçeğinden alınan puanların ortalamalarına bakıldığında eğitim fakültesi mezunu s1nıf öğretmenlerinin puanı $(X=72,16)$ diğer fakültelerden mezun olan sınıf öğretmenlerinin aldığ 1 puandan $(X=74,95)$ azdır. Ancak bu sayısal değerler istatistiksel olarak sinıf öğretmenlerinin mesleki doyum düzeylerinin en son mezun oldukları okul değişkenine göre farklılık gösterdiği anlamına gelmemektedir.

Tablo 14. Mesleki Doyum Ölçeği (Minnesota Doyum Ölçeği) Puanlarınn kıdem yılı değişkenine göre Aritmetik Ortalama ve Standart Sapma Değerleri

\begin{tabular}{llll}
\hline Değişken & $N$ & $X^{-}$ & $S s$ \\
\hline $\mathbf{1 - 5}$ yıl & 57 & 71,92 & 12,67 \\
\hline $\mathbf{6 - 1 0}$ yll & 100 & 71,47 & 14,76 \\
\hline $\mathbf{1 1 - 1 5}$ yıl & 57 & 73,84 & 12,06 \\
\hline $\mathbf{1 6 - 2 0}$ yll & 46 & 72,93 & 12,88 \\
\hline $\mathbf{2 1 - 2 5}$ yıl & 30 & 75,41 & 14,01 \\
\hline $\mathbf{2 6}$ yll ve üzeri & 112 & 98,62 & 11,36 \\
\hline Toplam & 402 & 72,81 & 13,05 \\
\hline
\end{tabular}

Mesleki doyum düzeyleri ifade eden ortalama puanlara bakıldığında 26 yıl ve üzeri $\left(X^{\prime}=98,62\right)$ kıdeme sahip öğretmenlerde en fazla, 6-10 yıl ( $\left.X=71,47\right)$ kıdeme sahip öğretmenlerde en az olduğu görülmüştür. 6-10 yıl kıdeme $(X=$ $71,47)$ sahip öğretmenlerin mesleki doyum düzeyleri, $1-5$ yıl kıdeme $(X=$ 
71,92), 11-15 yıl kıdeme ( $X=73,84), 16-20$ yıl kıdeme ( $X=72,93)$, $21-25$ yıl k1deme $(X=75,41)$, 26 yıl ve üzeri kıdeme ( $X=98,62)$ sahip öğretmenlerin mesleki doyum düzeylerinden daha düşük düzeyde olduğu söylenebilir.

Tablo 15. Mesleki Doyum Ölçeği (Minnesota Doyum Ölçeği) Puanlarının kıdem yılı değişkenine Göre Tek Yönlü Varyans (Tamhane) Analiz sonuçlan

\begin{tabular}{|c|c|c|c|c|c|c|}
\hline $\begin{array}{l}\text { Varyansın } \\
\text { Kaynağ1 }\end{array}$ & $\begin{array}{l}\text { Kareler } \\
\text { toplamı }\end{array}$ & $\begin{array}{l}\text { Kareler } \\
\text { Ortalaması }\end{array}$ & Sd & $\mathbf{F}$ & $\mathbf{P}$ & Anlamlı Fark Gruplanı \\
\hline Gruplar arası & 2037,47 & 407,49 & 5 & \multirow{3}{*}{2,43} & \multirow{3}{*}{0,34} & \multirow{3}{*}{26 yıl ve üzeri $>21-25$ yıl } \\
\hline Grup içi & 66254,15 & 167,30 & 396 & & & \\
\hline Toplam & 68291,632 & & 401 & & & \\
\hline
\end{tabular}

Sınıf öğretmenlerinin mesleki doyum düzeyleri kıdem yılı değişkeni açısindan anlamlı farklılık göstermektedir $(p<0,05)$. Analiz değerlerine bakıld1ğında grubun homojen dağılım göstermediği görülmüştür (Homojenite Varyans Testi $=$,043). Bu sebeple homojen dağılım göstermeyen gruplar için uygulanan Tek yönlü varyans analizi olan Tamhane uygulanmıştır. Değerler incelendiğinde sınıf öğretmenlerinin kıdem yılları mesleki doyum düzeylerinde anlamlı bir farklılaşmaya sebep olmuştur.

\section{Mesleki Doyum Ölçeğinden (Minnesota Doyum Ölçeği) Alınan Puanlarn Mesleği İsteyerek Seçip Seçmeme Değişkenine Göre Analiz Bulguları}

Sınıf öğretmenlerinin mesleki doyum düzeylerinin mesleği isteyerek seçip seçmeme değişkenine göre farklı olup olmadığına bakmak için t-Testi uygulanmiştır.

Tablo 16. Mesleki Doyum Ölçeği (Minnesota Doyum Ölçeği) Puanlarmin Mesleği İsteyerek Seçip Seçmeme Değişkenine Göre t-Testi Sonuçlarn

\begin{tabular}{|c|c|c|c|c|c|c|}
\hline Değişken & $\mathbf{N}$ & $X^{-}$ & ss & Sd & $t$ & $\mathrm{p}$ \\
\hline İsteyerek Seçtim & 342 & 73,27 & 12,86 & \multirow{2}{*}{400} & \multirow{2}{*}{1,70} & \multirow{2}{*}{, 085} \\
\hline İstemeyerek Seçtim & 60 & 70,16 & 13,89 & & & \\
\hline
\end{tabular}

Araştırmaya katılan sınıf öğretmenlerinin mesleki doyum düzeyleri mesleği isteyerek seçip seçmeme değişkenine göre anlamlı bir farklılık göstermemektedir $(p>0,05)$. Başka bir ifadeyle sınıf öğretmenlerinin mesleki doyum düzeyleri mesleği isteyerek seçip seçmemelerine bağlı olarak farklılaşmamaktadır. Mesleği isteyerek seçen sınıf öğretmenlerinin ( $X=73,27)$ mesleki aidiyet düzeyleri mesleği istemeyerek seçen sınıf öğretmenlerinin $(X=70,16)$ mesleki aidiyet düzeylerine göre daha yüksektir. 


\section{Tartışma ve Sonuç}

Sını öğretmenlerinin mesleki aidiyet duyguları ile mesleki doyum düzeyleri arasındaki ilişkinin incelendiği bu araştırmada: sınıf öğretmenlerinin mesleki doyum düzeyleri ile mesleki aidiyet duyguları arasında anlamlı ilişki olup olmadığı; mesleki doyum düzeylerinin cinsiyet, yaş, mezun olunan okul, mesleği isteyerek seçip-seçmeme değişkenlerine göre anlamlı bir farklılık gösterip göstermediği; mesleki aidiyet duygularının cinsiyet, yaş, mezun olunan okul, kıdem yıll, mesleği isteyerek seçip-seçmeme değişkenlerine göre anlamlı bir farklılık gösterip göstermediği incelenmiştir. Elde edilen sonuçlar ve bu sonuçlara ilişkin tartı̧malar aşağıda verilmiştir:

Araştırmanın problem durumu olan sınıf öğretmenlerinin mesleki aidiyet duyguları ile mesleki doyum düzeyleri arasında anlamlı ilişki olup olmadığı incelenmiştir. Analiz sonuçlarına göre mesleki doyum düzeyleri ile mesleki aidiyet duyguları birbiriyle ilişkili olarak artmaktadır. Araştırmaya katılan sınıf öğretmenlerinin mesleki aidiyet duyguları arttıkça mesleki doyum düzeyleri de artmaktadır. Yine mesleki doyum düzeyleri arttıkça mesleki aidiyet duyguları da artmaktadır denilebilir.

Öztaş (2010), öğretmenlerin mesleki aidiyetlerine ilişkin branş ve eğitim kademesi değişkenlerine göre istatistiksel olarak anlamlı bir farklılık olmadığını; statü, eğitim durumu, cinsiyet, çalıştığı kurum, okuldaki çalıma süresi ve mesleki kıdem değişkenlerine göre anlamlı farklılıklar olduğunu tespit etmiştir. Bu çalışma araştırmamızı desteklemektedir. Yürüten (2019) mesleki doyum ile mesleki aidiyet ölçeği alt boyutlarından mesleki görüş ve hak ve olanaklar ve kuruma aidiyet arasında pozitif yönde; iş birliği ve iletişim arasında ise negatif yönde ve anlamlı bir ilişki olduğunu tespit etmiştir. Bu çalışma araştırmamızı desteklemektedir.

Araştırmaya katılan 402 sınıf öğretmeninden bayan öğretmenlerin sayısı erkek öğretmenlerin sayısından fazladır. Yapılan analiz sonuçlarında cinsiyet değişkenine göre mesleki aidiyet duyguları incelendiğinde aralarında anlamlı bir farklılık olmadığı görülmüştür. Özmen, Özer ve Saatçioğlu (2005) çalışmasında cinsiyet ve örgütsel bağlllık ilişkisi ile ilgili gerçekleştirilen incelemede kadınların erkek meslektaşlarına oranla mesleki bağlılıklarının anlamlı bir farklılık göstermediğini analiz etmiştir. Bu çalışma araştırmamızı desteklemektedir. 
Araştırma sonuçlarında sınıf öğretmenlerinin mesleki aidiyet duyguları yaş değişkeni açısından anlamlı farklılık göstermediğine ulaşılmaktadır. Ceylan ve Bayram (2006) yaş değişkeninin örgütten ayrılma niyeti üzerinde istatistiksel olarak anlamlı etkisinin olmadığına ulaşmıştır. Baysal ve Paksoy (1999) yaş değişkeni değişkenler (mesleğe duygusal bağlılık, mesleğe devam isteği, kurumda devam isteği) arasında ilişki bulunamamıştır.

Sınıf öğretmenlerinin mesleki aidiyet duyguları en son mezun olunan okul değişkeni ile anlamlı farklılık göstermemektedir. Sönmezer (2007), çalışmasinda dershaneler ile özel ve resmi okullarda görev yapan öğretmenlerin iş tatminlerinin mezun olunan okul türüne göre anlamlı fark olduğunu sunmuştur.

Sınıf öğretmenlerinin mesleki aidiyet duyguları mesleği isteyerek seçip seçmeme değişkenine göre anlamlı bir farklılık göstermektedir. Karayağız (2018), sınıf öğretmenlerinin kurumsal aidiyet düzeylerini "tarafsızım" seviyesinde olduğunu görmüştür.

Sınıf öğretmenlerinin mesleki doyum düzeyleri cinsiyet değişkeni bakımından anlamlı farklılık göstermemektedir. Yılmaz (2018), alan değişikliğiyle özel eğitim okullarında çalışan sınıf öğretmenleri ile özel eğitim öğretmenlerinin mesleki doyum düzeyleri ile cinsiyet arasında anlamlı bir fark olmadığı sonucuna ulaşmıştır. Avşaroğlu ve arkadaşları (2005) öğretmenlerin iş doyumlarının cinsiyete göre anlamlı düzeyde farklılaşma saptamamıştır. Bu çalışmalar araştırmamızı desteklemektedir.

Yaş değişkeni sınıf öğretmenlerinin mesleki doyum düzeylerinde anlamlı bir farklılaşmaya sebep olmamıştır. Çağlıyan (2007), iş doyumu yaş değişkenine göre farklılık göstermediği sonucuna ulaşmıştır. Yücel ve Bektaş (2012), öğretmenler arasındaki yaş farklılıklarının, iş tatmini ve kurumsal bağlılık arasındaki ilişkilerde, belirleyici değil fakat ılımlı bir etkiye sahip olduğu belirlemişlerdir.

Sinıf öğretmenlerinin mesleki doyum düzeyleri en son mezun olunan okul değişkeni bakımından anlamlı farklılık göstermemektedir. Akkamış (2010) kişisel verilere göre ölçek maddelerini tek tek inceleyen araştırmacı, "Beni her zaman meşgul etmesi bakımından" maddesinde yüksek öğretmen okulundan mezun olan öğretmenlerde diğer mezunlara göre anlamlı farklılık olduğu sonucuna ulaşmıştır. Bu çalışma araştırmamızı desteklememektedir. 
Sınıf öğretmenlerinin mesleki doyum düzeyleri mesleği isteyerek seçip seçmemelerine bağlı olarak anlamlı farklılaşma oluşturmamaktadır. Aksayan (1990) hemşirelerin mesleği seçme nedenlerine göre iş doyumlarında anlamlı farklılık çıkmamıştır. Türkçapar (2012), öğretmenlerin mesleki doyum düzeylerinin mesleği isteyerek seçme durumlarına göre farklılık göstermediği sonucuna ulaşmıştır. Bu çalışmalar araştırmamızı desteklemektedir. 


\title{
EXTENDED ABSTRACT
}

\section{Investigation Of The Relationship Between The Primary School Teachers' Feelings Of Professional Belonging And Their Satisfaction Levels: Mersin Province Case}

\author{
Pelin Aydınol - Lütfi Üredi \\ Hüseyin Polat applied School of specail Education, Mersin University
}

Teachers create desired behaviors in individuals through education. Today, children begin their education life at an early age. The first social and educational environment created by preschool teachers continues with primary shool teachers. Primary school teachers are the ones who draw or change the individual's view of life. Practitioners of educational programs in schools and guide of students are primary shool teachers.Primary school teachers' sense of belonging to their professions, which guide the first steps of education, is very important in terms of work efficiency and student success. At the same time, the level of satisfaction that primary shool teachers experience in their professions for various reasons also affects student achievement. In this study, the relationship between professional teachers' sense of belonging and occupational satisfaction levels was examined.In this study, screening model was used by using quantitative research method. Research data were obtained by Occupational Belonging Scale and Minnesota Satisfaction Scale developed by Öztaş (2010). The Personal Information Form created by the researcher consists of independent variables. The population and sample of the study consisted of 402 primary school teachers working in official primary schools affiliated to the Ministry of National Education in Yenişehir, Toroslar, Akdeniz and Mezitli districts of Mersin during the 2018-2019 academic year. 58.7\% $(\mathrm{N}=236)$ of teachers were female and $41.3 \%(\mathrm{~N}=166)$ were male.Data were analyzed with SPSS 25.00 program. In the analysis of the data, correlation test was used for the problem case, T-test for unrelated samples, one-way analysis of variance (ANOVA) were used for the sub-problems. According to the results of the analysis, it was found that there was a significant difference $(p$ 
$<0.01$ ) between the sense of belonging and occupational satisfaction levels of the primary school teachers and there was a positive relationship.Primary school teachers' sense of professional belonging does not show a significant difference in terms of gender, age, marital status, last school graduation. Educational status and status at school could not be analyzed because they were not normally distributed for the group. The willingness to choose and not to choose the profession, seniority year and district variables studied make a significant difference in feelings of professional belonging. Vocational satisfaction levels of primary shool teachers do not make a significant difference in terms of gender, age, marital status, last graduated school, voluntary choice of profession, or district variables studied. The level of occupational satisfaction of primary shool teachers shows significant difference in terms of seniority variable. Vocational satisfaction levels in terms of educational status and status variables in the school could not be analyzed because the group did not show normal distribution.Suggestions were made in line with the researches and the results obtained.

\section{Kaynakça / References}

Akkamış, O. (2010). İlköğretim 1. ve u. kademe öğretmenlerinin iş tatmini üzerine bir değerlendirme. Yayımlanmış Yüksek Lisans Tezi. Yeditepe Üniversitesi Sosyal Bilimler Enstitüsü, İstanbul.

Aksayan, S. (1990). Koruyucu ve tedavi edici sağlık hizmetlerinde çalışan hemşirelerin iş doyumu etkenlerinin irdelenmesi. Yayımlamış Doktora Tezi. İstanbul Üniversitesi Sağlık Bilimleri Enstitüsü, İstanbul.

Arslan, M. (2001). İ̧̧ ve meslek ahlakı. Ankara: Nobel Yayın Dağtım.

Avşaroğlu, S., Deniz, M.E., ve Kahraman, A. (2005). Teknik öğretmenlerde yaşam doyumu, iş doyumu ve mesleki tükenmişlik düzeylerinin incelenmesi. Selçuk Üniversitesi Sosyal Bilimler Enstitüsü Dergisi, 14, 115-129.

Bağçeci, B., Çetin, B., Ünsal, S. (2013). Öğretmenlerin mesleki imaj ölçeği. Gaziantep University Journal of Social Sciences, 12 (1), 34-48.

Baycan, A. (1985). An analysis of the several aspects of job satisfaction between different occupational groups. Yayınlanmış Doktora Tezi. Boğaziçi Üniversitesi, İstanbul.

Baysal, A. C. ve Paksoy, M. (1999). Mesleğe ve örgüte bağllliğın çok yönlü incelenmesinde Meyer-Allen modeli. İstanbul Üniversitesi İşletme Fakültesi Dergisi, 28(1), 7-15. 
Beyazsaçlı, M. ve Bulut Serin, N. (2010). Devlet hastanelerinde görev yapan hemşirelerin iş doyum düzeylerinin incelenmesi: KKTC Örneği. International Conference on New Trends in Education and Their Implications, 979-986.

Ceylan, C. ve Bayram, N. (2006). Mesleki bağlılığın örgütsel bağlllık ve örgütten ayrılma niyeti üzerine etkilerinin düzenleyici değişkenli çoklu regresyon ile analizi. Atatürk Üniversitesi İktisadi ve İdari Bilimler Dergisi, 20(1), 105-120.

Christensen, L. B., Johnson, B., ve Turner, L. A. (2015). Araştırma yöntemleri: Desen ve analiz. Anı.

Çağlıyan, Y. (2007). Tükenmişlik Sendromu ve İş Doyumuna Etkisi: Devlet ve vakıf üniversitelerindeki akademisyenlere yönelik alan araştırması. Yayımlanmış Yüksek Lisans Tezi, Kocaeli Üniversitesi Sosyal Bilimler Enstitüsü, Kocaeli.

Erdoğan, S. (2006). Yeni yönetim anlayışı açısından aidiyet duygusu ve hizmet sektöründe bir uygulama. Yayımlanmış Yüksek Lisans Tezi, Uludağ Üniversitesi Sosyal Bilimler Enstitüsü, Bursa.

Gibson, J. L., Ivancevich, J. M., ve Donnelly, J. H. (2000). Organizations - behavior structure - processes. 10th Edition, Boston: McGraw-Hill.

Girgin, G. (2009). Öğretmenlerin iş doyumuna etki eden faktörlerin incelenmesi. $e$ Journal of New World Sciences Academy, 4 (4), 1298-1307.

Gülbahar, Y. ve Alper, A. (2009). Öğretim teknolojileri alanında yapılan araştırmalar konusunda bir içerik analizi. Ankara Üniversitesi Eğitim Bilimleri Fakültesi Dergisi, 42(2), 93-112.

Izgar, H. (2003). Endüstri ve örgüt psikolojisi. Konya: Eğitim Kitapevi Yayınları.

Karasar, N. (1994). Bilimsel araştırma yöntemi. (5. Baskı). Ankara: 3A Araştırma Eğitim Danışmanlik.

Karayağı, K. (2018). Illkokul öğretmenlerinin kurumsal aidiyet algısı ve mesleki yeterlilik algısı arasındaki ilişkinin incelenmesi. Yayımlanmış Yüksek Lisans Tezi, Yeditepe Üniversitesi Eğitim Bilimleri Enstitüsü, İstanbul.

Keskin, C. (2014). İlköğretim okullarnda örgütsel etkililik, mesleki doyum ve işten ayrnlma eğilimi. Yayınlanmış Doktora Tezi. Abant İzzet Baysal Üniversitesi Eğitim Bilimleri Enstitüsü, Bolu.

Mortimer, J. T. (1979). Changing attitudes toward work (Vol. 11). Work in Amer Inst.

Özmen, Ö. T., Özer, P. S. ve Saatçioğlu, Ö. Y. (2005). Akademisyenlerde örgütsel ve mesleki bağlılı̆̆ın incelenmesine ilişkin bir örnek araştırma. İşletme Fakültesi Dergisi, 6(2), 1-14.

Öztaş, S. (2010). Kadrolu, sözleşmeli ve ücretli statüye göre öğretmenlerin mesleki aidiyet duygusunun değerlendirilmesi. Yayımlanmış Yüksek Lisans Tezi, Gazi Üniversitesi Eğitim Bilimleri Enstitüsü, Ankara. 
Sönmezer, M. G. (2007). Millî Eğitim Bakanlı̆̆ı̀nda çalş̧an öğretmenler ile Milli Ĕ̆itim Bakanlığı'ndan emeklilik veya istifa nedeniyle özel eğitim kurumlarında çalışanların iş tatmin düzeylerinin karşllaştırmalı analizi. Yayımlanmamış doktora tezi. İstanbul Üniversitesi, İstanbul.

Tahta, F. (1995). Okul öncesi eğitim kurumlarnnda çalışan öğretmenlerin iş doyumu düzeylerinin incelenmesi. Yayımlanmamış Yüksek Lisans Tezi, Hacettepe Üniversitesi, Ankara.

Tekerci, H. (2008). Farkh okul öncesi eğitim kurumlarında çalışan öğretmenlerin mesleki doyumlarmmn ve tutumlarmin incelenmesi. Yayımlanmış Yüksek Lisans Tezi, Gazi Üniversitesi Eğitim Bilimleri Enstitüsü, Ankara.

Tekışık, H., H. (2014). Türkiye'de öğretmenlik mesleği ve sorunları. Hacettepe Üniversitesi Eğitim Fakültesi Dergisi, 2 (2), 24-33.

Tomakin, E. (2007). Bilimsel araştırma yöntemleri dersinin etkin öğretilmesinin incelenmesi. Atatürk Üniversitesi Kâzım Karabekir Eğitim Fakültesi Dergisi, (16), 3765.

Türkçapar, Ü. (2012). Beden eğitimi öğretmenlerinin farklı değişkenler açısından iş doyumu düzeylerinin incelenmesi. Gazi Üniversitesi Gazi Eğitim Fakültesi Dergisi, 32(2), 331-346.

Yılmaz, M. (2019). Sinfföğretmenlerinin mesleki kıdemlerinin, mesleki doyumlarmın, öz yeterlik inançlarnnın ve bireysel yenilikçiliklerinin kendini gerçekleştirme düzeylerine etkisi. Yayımlanmış Yüksek Lisans Tezi. Zonguldak Bülent Ecevit Üniversitesi Sosyal Bilimler Enstitüsü, Zonguldak.

Yiğit, A. (2007). Özel eğitim okullarnnda çalı̧̧an öğretmenlerin iş doyumu, tükenmişlik ve ruh sağ llk düzeylerinin çeşitli değişkenler açısından incelenmesi. Yayımlanmış Yüksek Lisans Tezi, Niğde Üniversitesi Sosyal Bilimler Enstitüsü, Niğde.

Yücel, I. ve Bektaş, C. (2012). Job satisfaction, organizational commitment and demographic characteristics among teachers in Turkey: Younger is better?. ProcediaSocial and Behavioral Sciences, 46, 1598-1608.

Yürüten, Z. M. (2019). Öğretmenlerin iş doyumlar, mesleğe aidiyet duygular ve mesleki tükenmişlik düzeyleri üzerine uygulamal bir araştırma. Yayımlanmış Yüksek Lisans Tezi, Selçuk Üniversitesi Sosyal Bilimler Enstitüsü, Konya. 


\section{Kaynakça Bilgisi / Citation Information}

Aydınol, P. ve Üredi, L. (2020). Sınıf öğretmenlerinin mesleki aidiyet duyguları ile mesleki doyum düzeyleri arasındaki ilişkinin incelenmesi : Mersin İli örneği. OPUS-Uluslararası Toplum Araştırmalar Dergisi, 16(Eğitim ve Toplum Özel Sayısı), 5681-5703. DOI: 10.26466/opus.755487 